\title{
Relaciones entre la muralla y la forma urbana a través de la cartografía: el caso de Teruel
}

\author{
Miguel Sancho Mir \\ Beatriz Martín Domínguez \\ Angélica Fernández-Morales
}

\section{Resumen}

La muralla fue un elemento determinante en la estructura de las ciudades medievales y ha marcado la evolución de su forma urbana. Es esta intensa relación entre la trama y la muralla el objeto la presente investigación, en este caso en Teruel, cuya fundación en el siglo XII, tuvo un finalidad estratégica y militar, como asentamiento de referencia en la conquista de Valencia.

El análisis se realiza con la cartografía como principal fuente y también como medio, ya que gracias a los Sistemas de Información Geográfica se ha podido estudiar esta de modo más riguroso y, además, se han podido crear cartografías historiográficas que permiten tener una visión evolutiva más clara y completa de esta interacción.

Se ha podido corroborar la importancia de la muralla sobre la forma de la fundación cristiana de Teruel, pero también su trascendencia a lo largo de la historia. El sistema defensivo de la ciudad evolucionó, se transformó con el tiempo, visto como un impedimento para el crecimiento y modernización de la ciudad, pero también fue reutilizado y modificado en los periodos bélicos, incluso hasta el siglo XIX. Un proceso que ha dejado su impronta, de mayor o menor modo, en la ciudad actual.

Palabras clave

muralla, forma urbana, cartografía, GIS, Teruel.
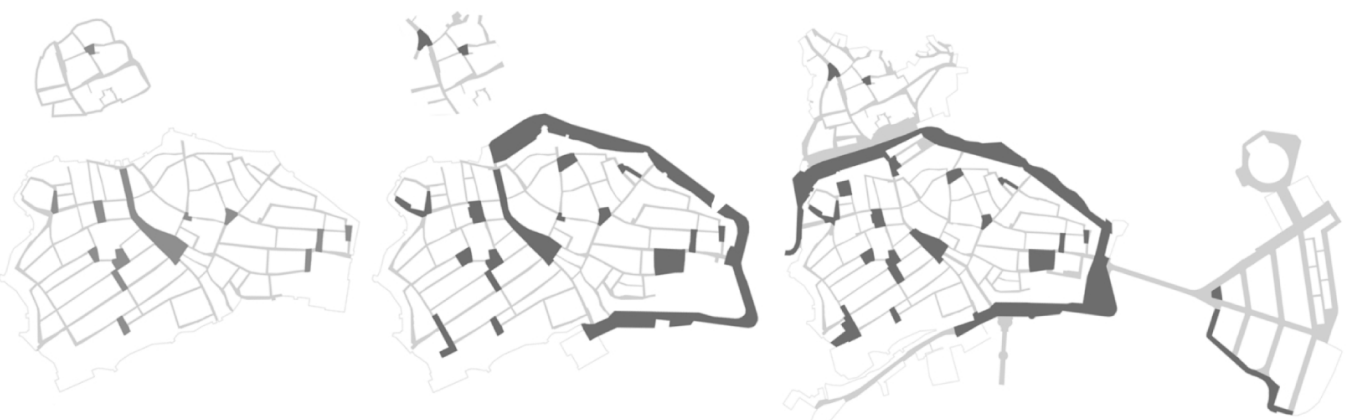


\section{Introducción}

La trama del centro histórico de Teruel es heredera de su periodo medieval, del que conserva su esquema general, aunque ha sufrido cambios significativos que han ido modelando la realidad urbana que hoy conocemos. El sistema defensivo, y en especial la muralla, es un elemento determinante para la evolución de la trama, y no sólo en su periodo fundacional, pues la formación y transformación del sistema defensivo fue un proceso continuo que duró hasta el mismo siglo XIX, y su huella quedó impresa en el urbanismo turolense para siempre. El estudio de esta intensa relación entre la trama y la muralla el objeto del presente trabajo. Un análisis que ha sido posible gracias al estudio de la cartografía histórica mediante la utilización de Sistemas de Información Geográfica. Para ello, tras la necesaria labor de archivo, se han utilizado las cartografías existentes previamente digitalizadas. Se ha realizado un proceso de coordinación cartográfica [Temes 2008, p. 68] de las mismas, tomando como base una planimetría actual que tiene la precisión topográfica necesaria, mediante su georrectificación o georreferenciación, según el caso, proceso en el que se le asigna valores métricos en un sistema de referencia [Balleti 2006, p. 34]. Lo que ha permitido conocer y corregir las deformaciones o inexactitudes de los documentos históricos, siempre cotejando con otras fuentes. Con esta información se han redibujado las cartografías historiográficas de los distintos periodos [Sancho, Agustín, Llopis 20 I7a]. A partir de I8II, que es la datación de la cartografía conocida más antigua de la ciudad, se han tenido que elaborar planimetrías basadas en la ley de persistencia del plano [Arizaga 2002, pp. 69, 70] y el resto de fuentes existentes, entre las que destacan los datos arqueológicos, bibliográficos y archivísticos.

De tal modo que el dibujo y la tecnología, la de la época utilizada para crear la propia cartografía, y la actual, para analizarla y redibujarla, han sido los medios necesarios para obtener los resultados deseados.

\section{Trama y muralla}

En agosto de I I7I, dos años después de su conquista, se decidió fortificar Teruel, debido a la gran inseguridad generada en las fronteras aragonesas tras la conquista almohade de Valencia, convirtiéndose en sede de una nueva tenencia y otorgándole el Fuero de la cercana Daroca. Es a partir de este momento cuando se podrían datar los inicios de la intervención urbanística cristiana en la ciudad, que sería ocupada en un principio por el tenente mandado por el monarca, acompañado por su hueste $y$, seguramente también, por un grupo de gentes que viviría de prestar los servicios básicos a los militares allí destinados. Desde este instante empezaría la afluencia de nuevos colonos, que en este primer periodo no sería de gran magnitud, pues la concesión por Alfonso II del fuero propio de Teruel, en I 177, denota la necesidad urgente de atraer a nuevos pobladores para afianzar una posición tan importante para los intereses de los aragoneses, que actuaría como punta de lanza hacia la conquista de las tierras musulmanas. Los fueros propios fueron concedidos con motivo de la fundación de la nueva villa de Teruel, el I de octubre de I 177 [Gargallo 1996, p. 96], independizándola de Daroca y concediéndole toda la parte meridional de su territorio para constituir su término municipal. A partir de este momento la villa experimentó un rápido crecimiento demográfico y urbano, con lo que Teruel se convirtió en la localidad más importante de la frontera sur de Aragón.

El asentamiento se emplazó en lo alto de una muela rodeada por escarpadas laderas. El trazado de la muralla se adaptó a su perímetro, aprovechando la topografía, y su irregular forma condicionó la morfología urbana, que debió adaptarse a un espacio de aproximadamente 17 hectáreas delimitado de antemano.

El trazado planteado en las planimetrías es consecuencia de los restos visibles de la muralla, los restos existentes en el interior de edificios, excavaciones arqueológicas, así como, del análisis de las cartografías históricas. Esto ha permitido que prácticamente todo el perímetro, menos el entorno de la puerta de Valencia, en la cornisa sur, quede claramente ubicado y definido, a falta de la disposición exacta de gran parte de los torreones con los que debía contar la misma. 
Fig. I. Hipotético plano con los principales elementos del sistema defensivo de Teruel a mediados del siglo XIV. Elaboración propia.

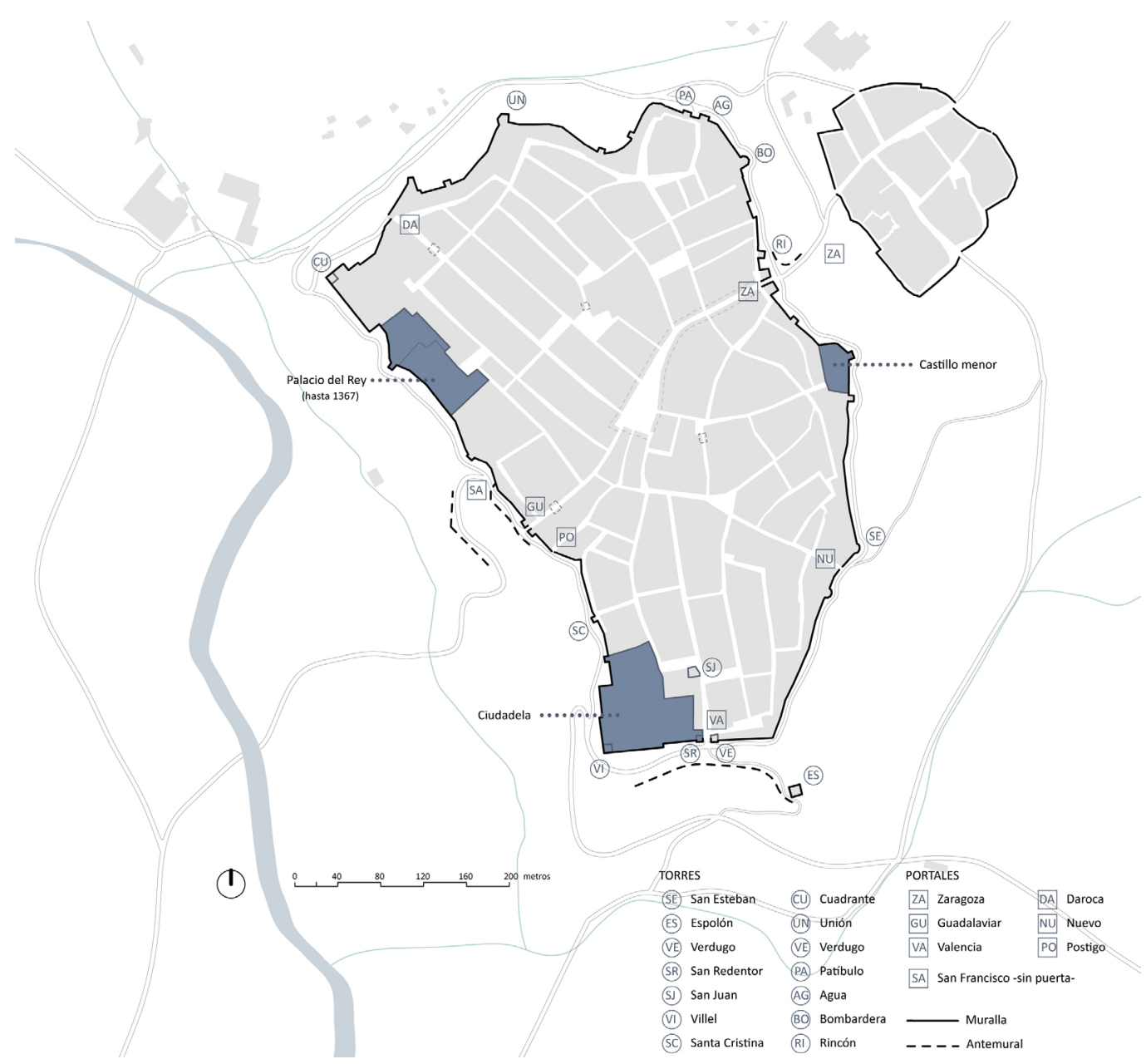

En la zona que ocupaba la Ciudadela, la devastación producida en la Guerra Civil junto con otras operaciones urbanas, no han permitido corroborar el exacto trazado de la muralla, por lo que ha habido que realizar una hipótesis, utilizando la huella de la edificación existente antes de la Guerra, el Gobierno Civil, anteriormente convento de Santo Domingo. Hipótesis apoyada por el hecho de que no se encontraron restos de muralla en las excavaciones para la reciente construcción de un aparcamiento subterráneo bajo la Glorieta. En la zona sureste, se ha seguido el mismo criterio, pese a que algunos autores extendín la muralla hasta la conocida como torre del Espolón, se ha desechado esta hipótesis por la interpretación un texto del siglo XV que dice que existía una era entre la citada torre y la muralla [Muñoz 2007, p. 54] La figura I muestra el hipotético plano con los principales elementos del sistema defensivo de Teruel a mediados del siglo XIV [I].

La estructura viaria se apoyó en un eje principal que une la puerta de Zaragoza con la de Guadalaviar, que divide el núcleo en dos áreas. En la zona noroeste de trazado regular, consecuencia del reparto del suelo para los nuevos pobladores. Mientras que en la zona sureste se pueden apreciar dos tramas urbanas claramente diferenciadas: al sur, una trama cuasi-regular, condicionada por la implantación de un gran número de edificios de carácter defensivo y religioso; y en la parte este se ubica una zona con un trazado de estructura radio-concéntrica, que se adapta a la orografía de la zona.

El irregular espacio intersticial entre la trama y el trazado de la muralla, ocupado por construcciones vinculadas con el sistema defensivo o por huertos y corrales, paulatinamente, fue absorbido por el propio caserío en el proceso de densificación y colmatación del espacio intramuros. La plaza Carlos Castel, emplazada en el centro, articula las diferentes tramas y dota de unidad al conjunto urbano. Desde este espacio parten también las arterias consideradas de segundo orden, que lo conectan con las puertas de Valencia y de Daroca (fig. 2). 


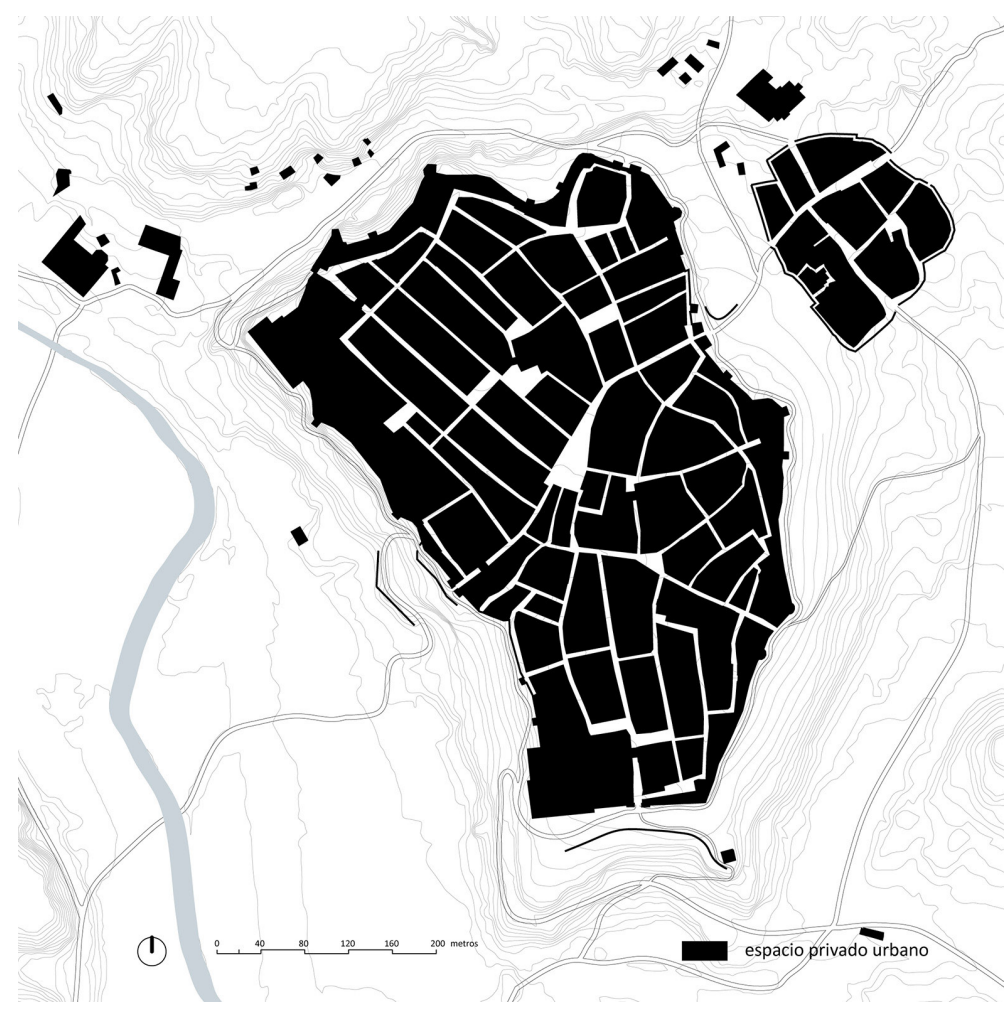

El sistema defensivo sufrió cambios significativos en el siglo XVIII, con la construcción de varias instituciones religiosas. Mas intensos fueron durante el siglo XVIII, mediante un proceso de derribo y ocultación. Durante la guerra de sucesión sufrió importantes desperfectos [Alcorán, S.XII al S.XVIII, fol. I 07], pero las causas principales fueron el crecimiento demográfico, así como el desarrollo de la masa edilicia, por las propias necesidades de expansión y por el asentamiento de nuevas instituciones religiosas [Alcorán, S.XII al S.XVIII, fol.I07]. También se demolieron los torreones del portal de Guadalaviar, así como el propio portal para mejorar el acceso a la ciudad [Alcorán, S.XII al S.XVIII, fol. I 80], aunque debió ser reconstruido posteriormente (fig. 3). Durante este periodo no varió el esquema general de la trama, sin embargo, se produjeron importantes cambios en cuanto a la sintaxis de su trazado, con la aparición de nuevas calles

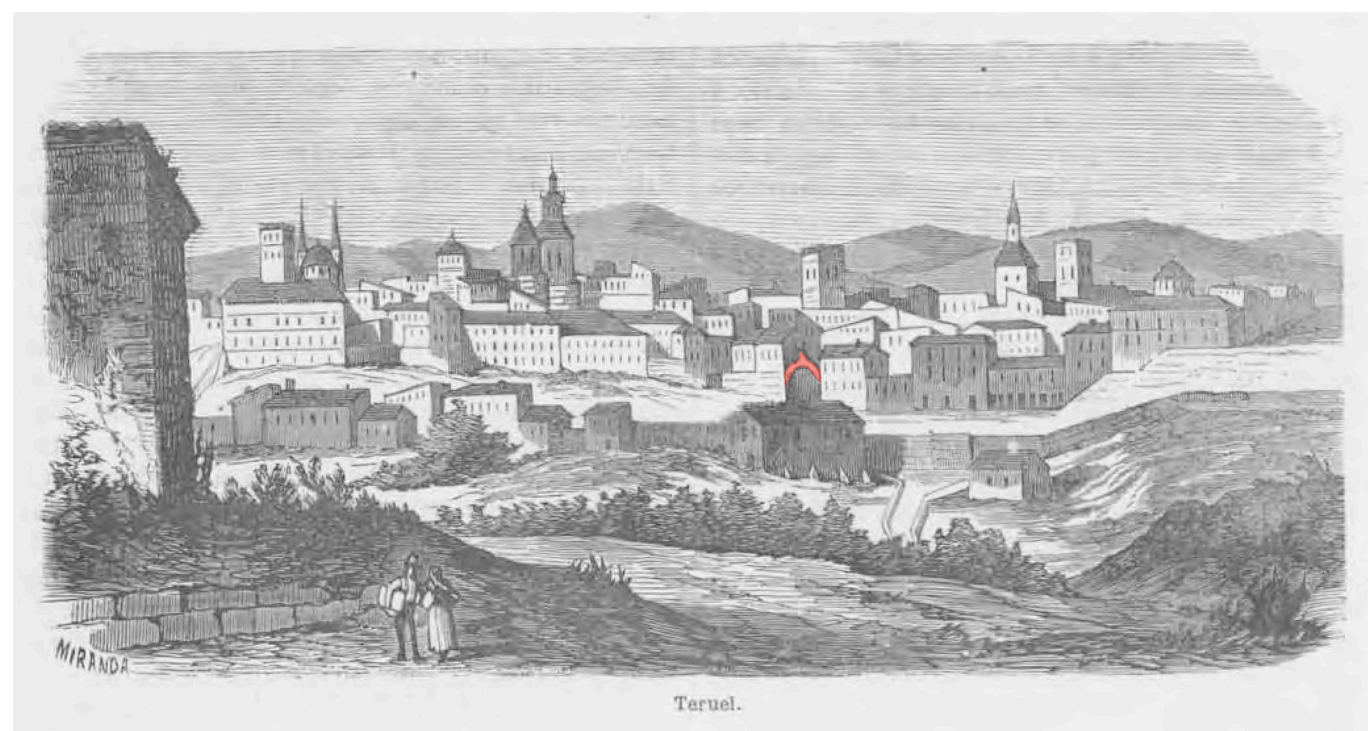




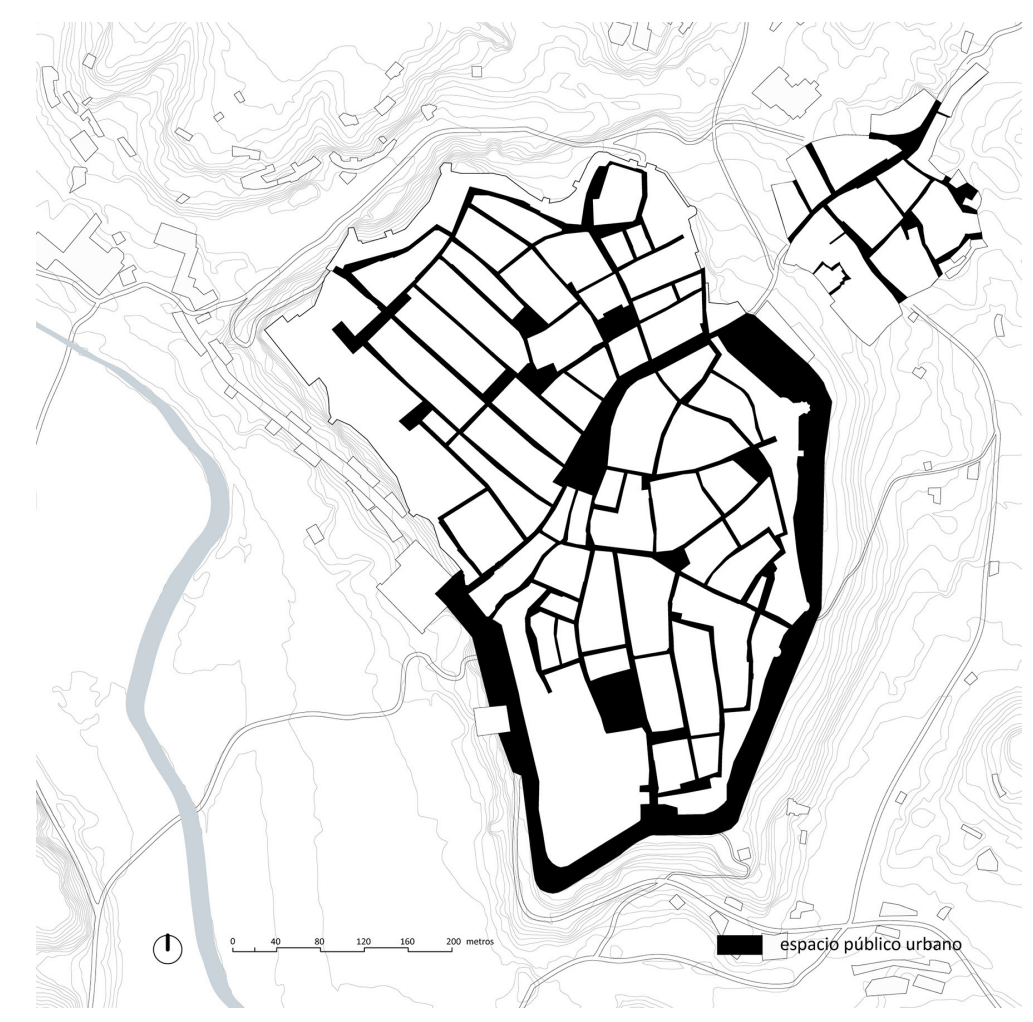

en el núcleo consolidado y la formación de nuevas vías extramuros, y a la configuración espacial, con la creación de plazas tanto en el interior como en el exterior del recinto (fig. 4). En el inicio del siglo XVIII el espacio urbano sobrepasó los límites de la muralla [Alcorán, S.XII al S.XVIII, fol. I07], en un proceso de modernización en el que existía una mayor preocupación por la creación y mejora de espacios de esparcimiento [Sancho, Agustín, Llopis 20 l 7b]. Se generaron paseos y alamedas en torno al núcleo con unas condiciones higiénico-sanitarias óptimas en los que se plantaron árboles que los dotaban de calidad.

Así, a mediados del siglo XVIII, la ciudad ya contaba con un largo y espacioso paseo que, desde el noreste de la ciudad, rodeaba la ciudad por el sur hasta llegar al portal de Guadalaviar. Este paseo, condicionado por el primitivo trazado de la muralla, se situó extramuros y sobre la muela, donde previamente existía un estrecho camino, por lo que hubo que terraplenar la ladera para ganar el espacio necesario para su creación (fig. 5).

En los albores del siglo XIX la muralla se encontraba en proceso de abandono, vista como un impedimento para la expansión y modernización del espacio urbano, por lo que fue derribada en algunas partes y tapada en otras, aunque aún era visible en gran parte del perímetro [Miñano y Bedoya I826-I828, t.VIII, p. 423].

Pero todo cambió en el siglo XIX debido a la ocupación francesa y, más tarde, a la defensa de la ciudad frente a los carlistas. La adaptación del recinto para su defensa requirió de un efímero complejo sistema de fortificación [Sancho, Agustín, Martín 2017], que supuso una transformación que tuvo un gran impacto sobre la ciudad, modificando la morfología y la función de los paseos que circunvalaban la muela. Se realizó una nueva muralla encerrando estos paseos, y se modificó y amplió la existente en algunos puntos como el tramo que une los torreones del Agua y la Bombardera. Se trataba de una tapia realizada con yeso, y de poca altura y espesor que transformó el espacio urbano en un sistema abaluartado, ya en decadencia en la época, [Clairac y Saénz 1884, III, I59], pero que permitió una mejor defensa del emplazamiento. A este nuevo trazado se le practicaron dos accesos en la cornisa oeste, uno en el paseo del Ovalo al que se llegaba desde el camino de Valencia, y otro en la parte superior de la calle San Francisco, y se completaron con dos de los medievales que aún permanecían, el de Zaragoza al este y el de Daroca al norte. Durante este siglo, 
Fig. 5. Evolución del espacio público urbano de Teruel hasta el S.XX con las plazas y los paseos urbanos.
Elaboración propia.

Fig. 6. Montaje en el que se destaca el espacio de paseos y alamedas entre murallas en la primera guerra carlista sobre detalle del plano de Teruel de 1835.

Nota: rotado respecto

al original, con el norte orientado hacia la

derecha. Elaboración propia (CEME 1835 [plano]).
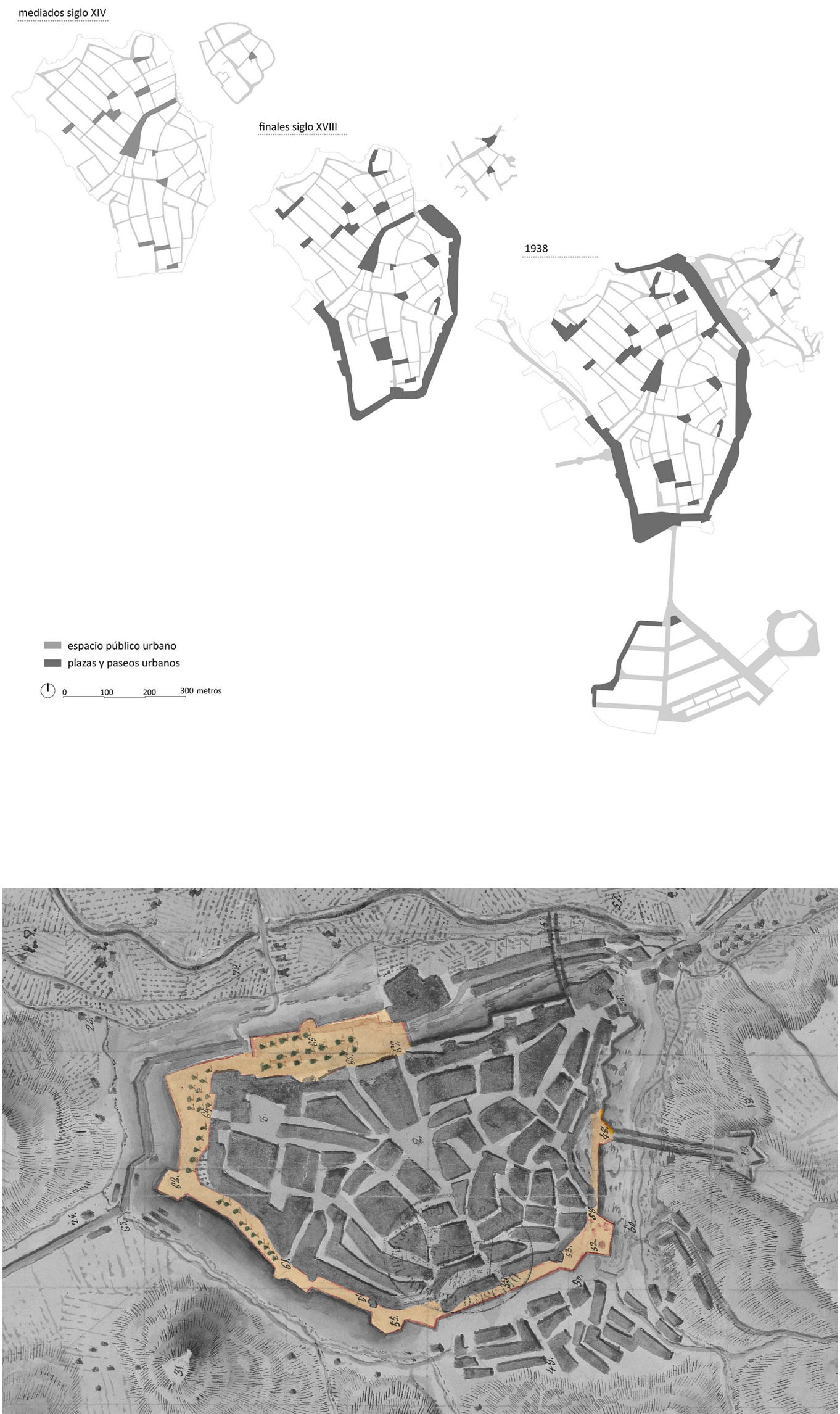
además, siguió el crecimiento de la masa edilicia, como ocurrió en la fachada noreste y este de la ciudad, donde la parte posterior de muchos de los nuevos edificios se apoyan en la traza de la muralla y formalizan la nueva fachada del paseo creo en el siglo XVIII, proceso que durante esa centuria ya se produjo en el actual paseo del Ovalo, de tal modo que en 1866 eran muy pocos los tramos visibles [Pruneda 1866, p. 33] (figs. 6, 7).

La construcción del Puente de la Reina al norte de la ciudad, cuyo proyecto data de I835, transformó la función del paseo que circunvalaba la muela, cuya disposición derivaba del trazado de la muralla, de un espacio para el esparcimiento en una vía de comunicación para el tráfico rodado, la carretera de Teruel a Alcañiz. La imposición del automóvil, intensificó este cambio y desvirtuó su concepción original. De tal modo, que el trazado de esta infraestructura, de carácter regional, es consecuencia de la disposición de la primitiva muralla medieval. Además, conectando con esta ronda, en frente del antiguo portal de Valencia, se construyó en 1929 el Viaducto, que daría conexión a la carretera de Sagunto.

Las guerras carlistas fueron el último acontecimiento bélico donde la muralla tuvo un papel crucial, ya que, en la Guerra Civil de 1936 los avances armamentísticos supusieron un cambio radical en los enfrentamientos. Tras la devastación sufrida, el proyecto de reconstrucción de la ciudad se entendió como una oportunidad para renovar la trama urbana. Por suerte, las ideas más reformistas pensadas al servicio tráfico rodado, que hubieran borrado gran parte del trazado medieval, no triunfaron, mientras que la propuesta ejecutada, aunque supuso cambios importantes, guarda gran parte de la identidad, de la huella de la ciudad histórica.

\section{Conclusiones}

La muralla no es un elemento estático, sino que ha sufrido importantes procesos de cambio desde su construcción en el siglo XIl; transformaciones formales y materiales, degradaciones derivadas de la colmatación del espacio edilicio y de su abandono o como consecuencia de los periodos bélicos, de tal modo que configuración original fue evolucionando y condicionando la forma de la ciudad.

El estudio de la cartografía histórica de Teruel, realizado de una forma más rigurosa y precisa gracias a las nuevas tecnologías, ha permitido verificar la influencia que ha tenido el trazado de

Fig. 7. Fotomontaje resaltando elementos de una fotografía del siglo XIX, cornisa suroeste. Elaboración propia. Archivo fotográfico de Antonio Pérez.

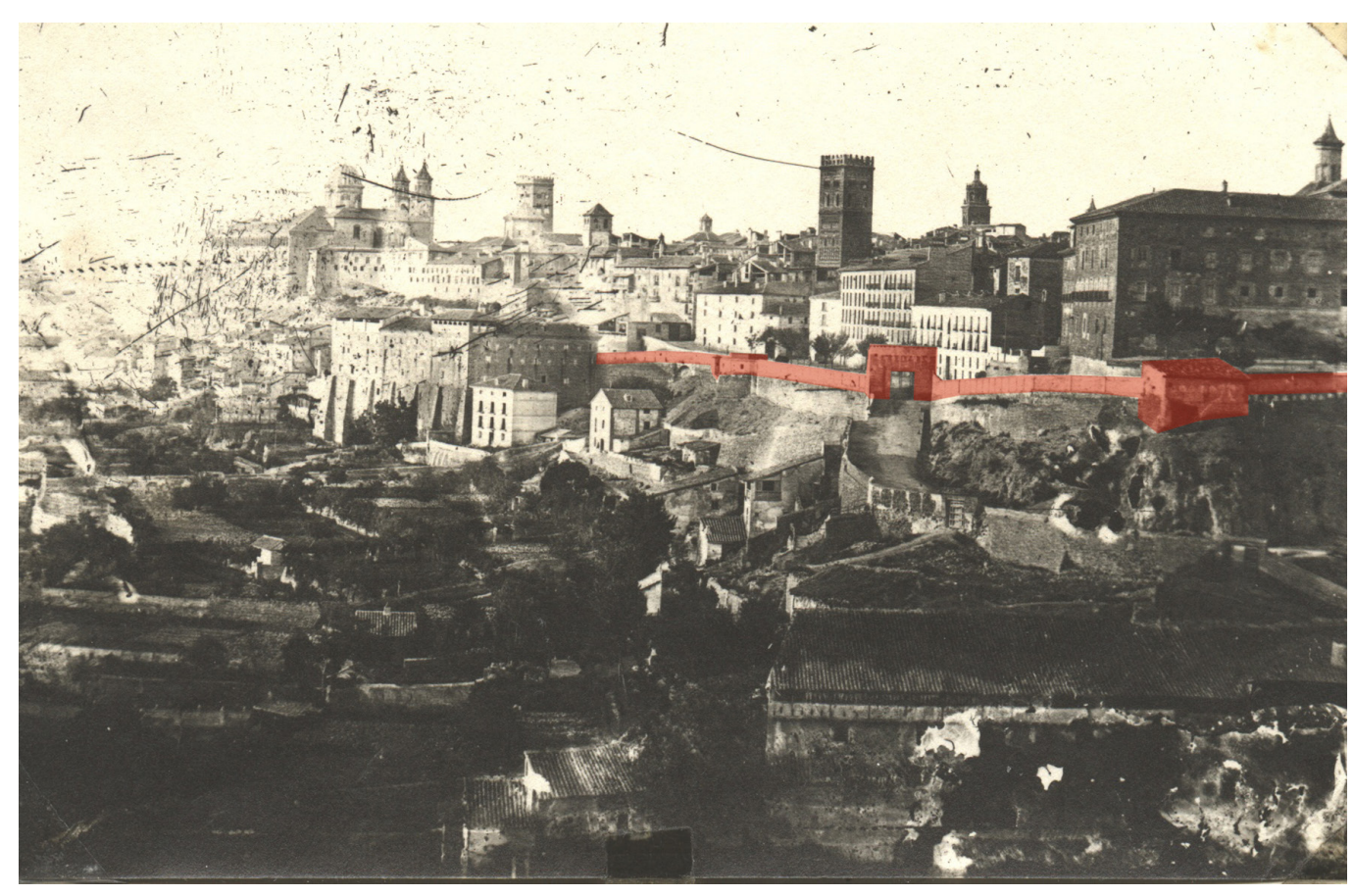


la muralla en la evolución de la morfología urbana, desde la configuración inicial de su trama y estructura, a la densificación del espacio urbano derivado de la limitación impuesta por su presencia, a la disposición de muchos de los edificios institucionales o los paseos como espacios públicos adosados al exterior de la misma, posteriormente convertidos en viales para la circulación del automóvil. Una huella, como se ha visto, que ha perdurado en la memoria de las trazas hasta nuestros días, a pesar de los ya bastante escasos restos conservados.

\title{
Agradecimientos
}

Investigadores del Grupo de investigación en Arquitectura de la Universidad de Zaragoza GIA, financiado por el Gobierno de Aragón [Referencia Grupo T37_I7R] y cofinanciado con Feder 20 I4-2020 Construyendo Europa desde Aragón.

\section{Notas}

[I] En realidad, debieron existir más torreones de los representados, pero no se han incluido al no conocer su situación exacta o su forma.

\section{Referencias}

Alcorán o Libro Verde. s. XII al S. XVIII. [Manuscrito]. Inédito. Archivo Histórico Provincial de Teruel (AHPTE), Concejo/36/03. 284 fol.

Arizaga Bolumburu B. (2002). La imagen de la ciudad medieval: la recuperación del paisaje urbano. Santander: Editorial of the University of Cantabria.

Balleti C. (2006). Georeference in the analysis of the geometric content of early maps. In e-Perimetron [electronic resoiurce]. vol. I, n. I, pp. 32-42.

Clairac y Saénz P. ( 1884) Diccionario general de arquitectura e ingeniería., volume III. Madrid: Press of A. Pérez Durrull.

Cuerpo del Estado Mayor del Ejército (España) (1835). Sketch of Teruel and its surroundings [map]. [ca. I: 6,800]. Unpublished. $560 \mathrm{~mm} \times 660 \mathrm{~mm}$. In España. Ministry of Defence. Institute of Military History and Culture. General Military Archive of Madrid. (IHCM_TE-3-4).

Gargallo Moya A.J. ( 1996). El concejo de Teruel en la Edad Media, I 177- I 327.Teruel: Department of Culture and Education of the Government of Aragon / Teruel City Council / Escucha City Council.

Miñano y Bedoya S. (I826-1828). Diccionario geográfico-estadístico de España y Portugal., volume VIII. Madrid: Press of Pierart-Peralta.

Muñoz Garrido V. (2007). Teruel: de sus orígenes Medievales a la pérdida del fuero en 1598. Zaragoza: Ino Press.

Pruneda P. ( 1 866). Chronicle of the province ofTeruel written by Pedro Pruneda. In Crónica general de España. Madrid: Ronchi and Co.

Sancho Mir M., Agustín Hernandez L., Llopis Verdú J. (20 I7a) Análisis y generación de cartografías historiográficas en el estudio de la evolución de la forma urbana: el caso de la ciudad de Teruel. In EGA Revista de expresión gráfica arquitectónica, vol. 30 , pp. $180-189$.

Sancho Mir M., Agustín Hernández L., Llopis Verdú J. (20 I7b). Hacia una nueva concepción del espacio público en el Teruel de la Edad Moderna: desde el S.XVI hasta el inicio del S.XIX. In ACE Architecture, City and Environment = Arquitectura , Ciudad y Entorno, n. 12 (35), pp. 191-212.

Sancho Mir M., Agustín Hernández L., Martín Domínguez B. (20 I7). La fortificación de Teruel durante el siglo XIX: un paisaje efímero. In Arqueología de la Arquitectura, n. I 4.

Temes Cordovez R.R. (2008). Las fuentes catastrales y la identificación de las transformaciones en los tejidos inversos. In CT: Catastro, n. 64, pp. 55-78 <http://wnw.catastro.meh.es/documentos/publicaciones/ct/ct64/n64_3.pdf> (consultado el 23 February 202I).

\author{
Autores \\ Miguel Sancho Mir, Universidad de Zaragoza, misanmi@unizar.es \\ Beatriz Martín Domínguez, Universidad de Zaragoza, beamardo@unizar.es \\ Angélica Fernández-Morales, Universidad de Zaragoza, af@unizar.es
}

Para citar este artículo: Sancho Mir Miguel, Martín Domínguez Beatriz, Fernández-Morales Angélica (202I). Relaciones entre la muralla y la forma urbana a través de la cartografía: el caso de Teruel/Relations between the Wall and Urban form through Cartography: the Case of Teruel. In Arena A., Arena M., Mediati D., Raffa P. (a cura di). Connettere. Un disegno per annodare e tessere. Linguaggi Distanze Tecnologie. Atti del $42^{\circ}$ Convegno Internazionale dei Docenti delle Discipline della Rappresentazione/Connecting. Drawing for weaving relationship. Languages Distances Technologies.

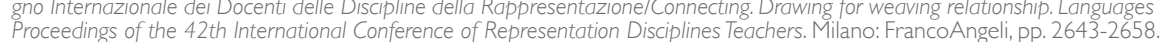




\title{
Relations between the Wall and Urban Form through Cartography: the Case of Teruel
}

\author{
Miguel Sancho Mir \\ Beatriz Martín Domínguez \\ Angélica Fernández-Morales
}

Abstract

The wall was a key element in the structure of medieval cities and has marked the evolution of their urban form. It is this intense relationship between the urban pattern and the wall that is the subject of this research, in this case relating to Teruel, whose foundation in the $12^{\text {th }}$ century had a strategic and military purpose, as an important settlement for the conquest of Valencia.

The analysis is performed using cartography as the main source and also as a medium, since thanks to Geographic Information Systems it was possible to study the question more rigorously and, also, to create historiographic cartographies that allow us to have a clearer and more complete vision of how the relationship evolved.

We were able to corroborate the importance of the wall on the form of Teruel's foundation as a Christian city, and also its relevance throughout history. The defensive system of the town evolved, and changed through time. It was at times seen as an impediment to the growth and modernisation of the town, but was then reused and modified in times of war, even up to the $19^{\text {th }}$ century. A process that has left its imprint, to a greater or lesser extent, on the current city.

Keywords

wall, urban form, cartography, GIS, Teruel.

Evolution of Teruel's urban public space until the 20th century with plazas and tow promenades. Ow drawing.
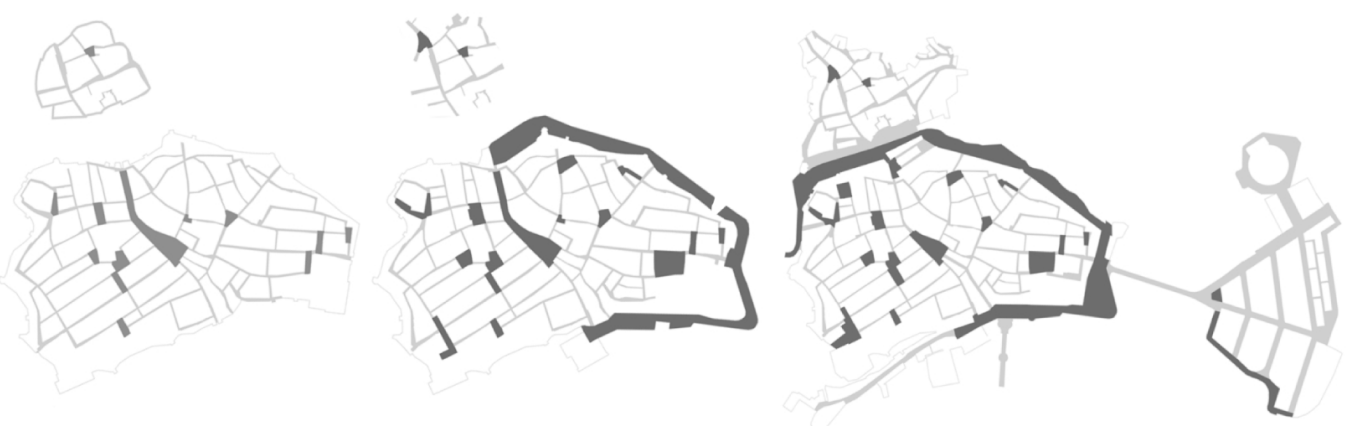


\section{Introduction}

The urban pattern of the historic centre of Teruel is a legacy of the medieval period, whose general layout has been retained, although significant changes have been made to refashion the town's streets as we know them today. The defensive system, and especially the wall, is a key element in the evolution of the urban fabric, and not only in its founding period, as the formation and transformation of the defensive system was a continuous process that lasted until the $19^{\text {th }}$ century, leaving its mark on Teruel's urban plan forever. This intense relationship between the urban pattern and the wall is the subject of this study.

An analysis was possible thanks to a study of historical cartography through the use of Geographical Information Systems. To this end, after the necessary archive work, previously digitised existing cartographies were used. A process of cartographic coordination [Temes 2008, p.68] has been carried out on them, taking as a basis a current planimetry that has the necessary topographic precision, through its georectification or georeferencing, depending on the case, a process in which metric values are assigned in a reference system [Balleti 2006, p.34]. This made it possible to identify and correct any deformations or inaccuracies in historical documents, simply by cross-checking with other sources. With this information, the historical cartographies of the different periods have been redrawn [Sancho, Agustín, Llopis 2017a]. From I 8 I I onwards, the date of the oldest known map of the city, planimetries have had to be drawn up based on the law of persistence of the plan [Arizaga 2002, pp. 69-70] and other existing sources, among which archaeological, bibliographical and archival data are prominent. This means that the drawing techniques and the technology used to create the cartography of the time, and those used today to analyse and redraw it, have both been needed to obtain the desired results.

\section{Urban pattern and Wall}

In August I I 7I, two years after its conquest, it was decided to fortify Teruel, due to the great insecurity generated on the Aragonese borders after the Almohad conquest of Valencia, at the same time making it the seat of a new administration and conferring it the Charter of nearby Daroca. Dated from this time, are the beginnings of Christian urban development in the town, which would be occupied at first by the lieutenant of the garrison appointed by the monarch, accompanied by his host and, probably also, by a group of people who lived nearby providing basic services to the soldiers stationed there. From this date, also, the influx of new settlers would begin, which initially was not particularly significant, as the granting by Alfonso II of Teruel's own charter in I I 77 indicates the urgent need to attract new settlers to consolidate such an important position for Aragonese interests, which would act as a spearhead for the eventual conquest of the Muslim lands. Its own privileges were granted on the occasion of the foundation of the new town ofTeruel, on I October I 177 [Gargallo 1996, p. 96], making it independent from Daroca and granting it the entire southern part of its territory to constitute its municipal district. From this moment on, the town experienced rapid demographic and urban growth, making Teruel the most important town on the southern border of Aragon.

The settlement was located on top of a hill surrounded by steep slopes. The layout of the wall was adapted to its perimeter, taking advantage of the topography, and its irregular shape conditioned the urban morphology, which had to be adapted to a space restricted to approximately 17 hectares.

The layouts proposed in the planimetries is a consequence of the visible remains of the wall, the existing remains within buildings, archaeological excavations and an analysis of historical cartography. This has allowed practically the entire perimeter, except for the area around the Valencia gate, on the southern cornice, to be clearly located and defined, in the absence of the exact arrangement of most of the turrets that the wall should have had.

In the area occupied by the Ciudadela, the devastation caused by the Civil War as well as other town planning activity, has prevented us from establishing the exact layout of the wall, and therefore 
Fig. I. Hypothetical plan with the main features of Teruel's defensive system mid-1 $4^{\text {th }}$ century. Own drawing.

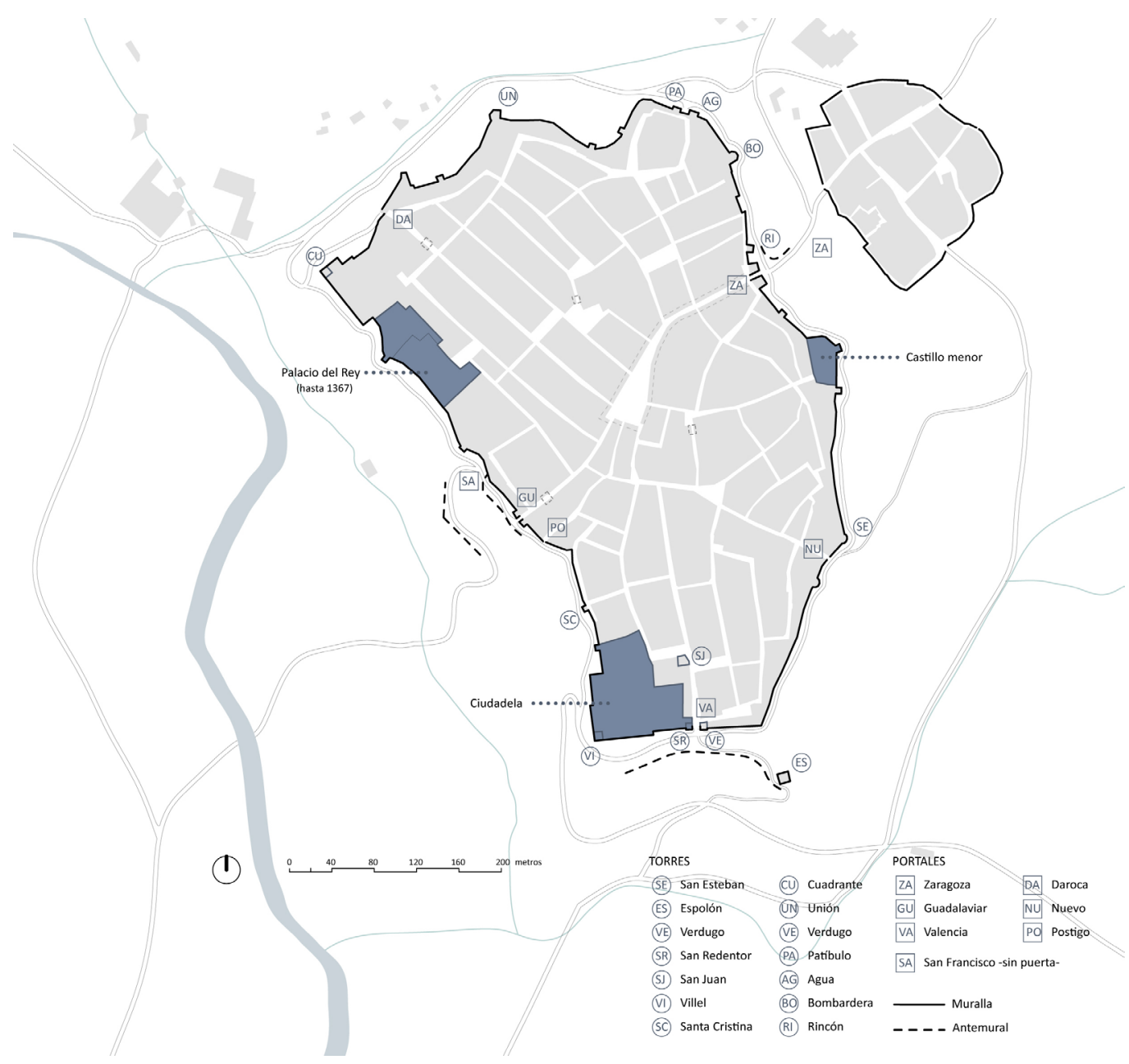

a hypothesis had to be made, using the building footprint that existed before the Civil War, the seat of Civil Government, previously the convent of Santo Domingo. The hypothesis is supported by the fact that no wall remains were found in excavations for the recent construction of an underground carpark beneath the Glorieta. In the southeast area, the same criterion has been followed, despite the fact that some authors extended the wall to what is known as the Espolón tower, a theory which has been discarded due to the interpretation of a $15^{\text {th }}$ century text which states that there was a threshing floor between the aforementioned tower and the wall [Muñoz 2007, p. 54]. Figure I shows the hypothetical plan with the main elements of Teruel's defensive system in the mid-fourteenth century $[\mathrm{I}]$.

The street plan is based on a main axis that links the Zaragoza and Guadalaviar gates, dividing the centre into two areas. In the north-west, a regular layout results from the distribution of land to the new settlers. While in the southeast two clearly differentiated urban plots can be seen: to the south, a quasi-regular plot, conditioned by the construction of a large number of buildings of a defensive and religious nature; and in the eastern part there is an area with a radio-concentric layout, which adapts to the orography of the area.

The irregular interstitial space between the pattern and the layout of the wall, occupied by constructions linked to the defensive system or by vegetable gardens and corrals, was gradually absorbed by the houses themselves in the process of densifying and filling the space inside the walls. The plaza Carlos Castel, lying in the centre, articulates the different grids and gives unity to the whole plan. Streets considered as secondary radiate out from the plaza towards the Valencia and Daroca gates (fig. 2).

The defensive system underwent significant changes in the $17^{\text {th }}$ century, with the construction of several religious institutions. The pace of change intensified during the $18^{\text {th }}$ century, with a 


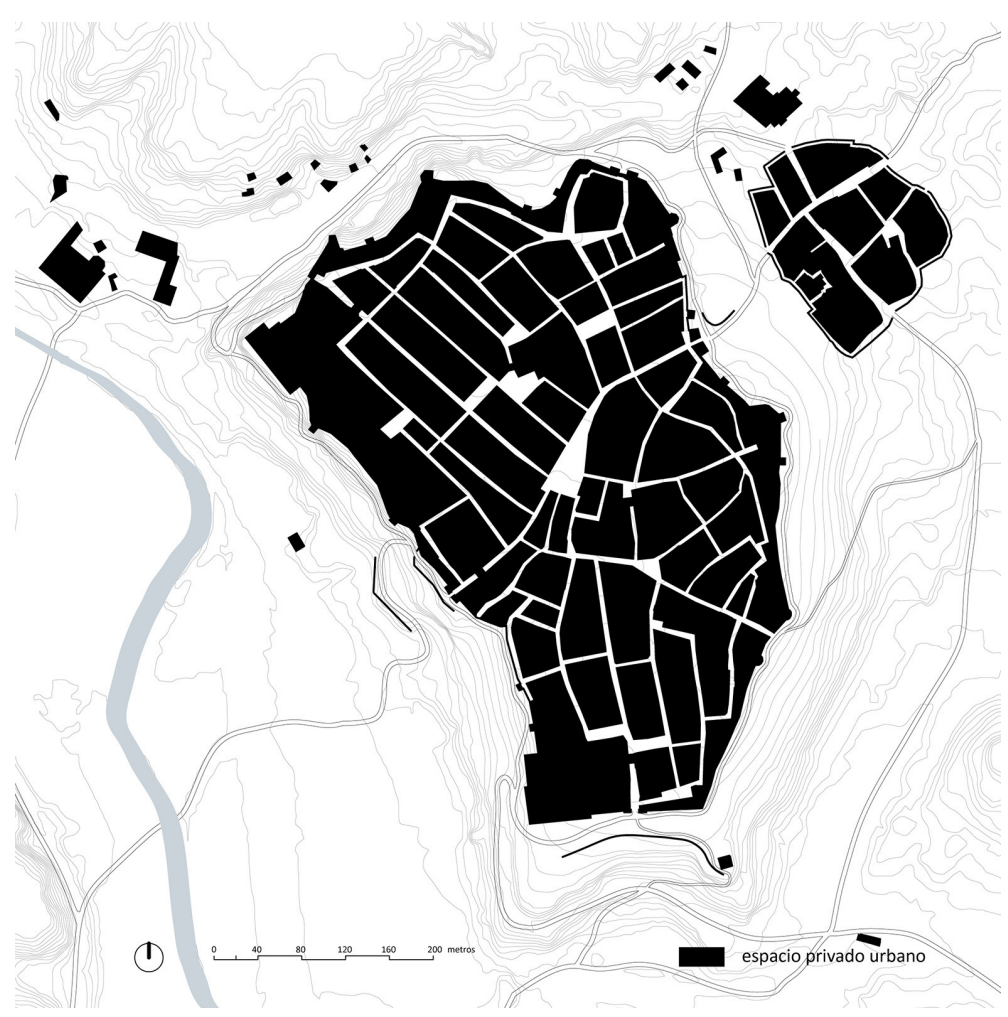

process of demolition and concealment. During the War of Succession, it suffered significant damage [Alcorán, $12^{\text {th }}$ to $18^{\text {th }}$ century, fol. I07], but the main causes were demographic growth, as well as the greater density of construction, due to the needs of expansion and the settlement of new religious institutions [Alcorán, $12^{\text {th }}$ to $18^{\text {th }}$ century, fol. 107$]$. The towers of the Guadalaviar gate were also demolished, as well as the gateway itself to improve access to the city [Alcorán, $12^{\text {th }}-18^{\text {th }}$ C., fol. I 80], although it must have been rebuilt later (fig. 3).

During this period the general grid scheme did not change, however, important changes took place in the layout structure, with the appearance of new streets in the consolidated city centre and the creation of new extramural roads, and in the spatial configuration, with the creation of plazas inside and outside the walls (fig. 4).

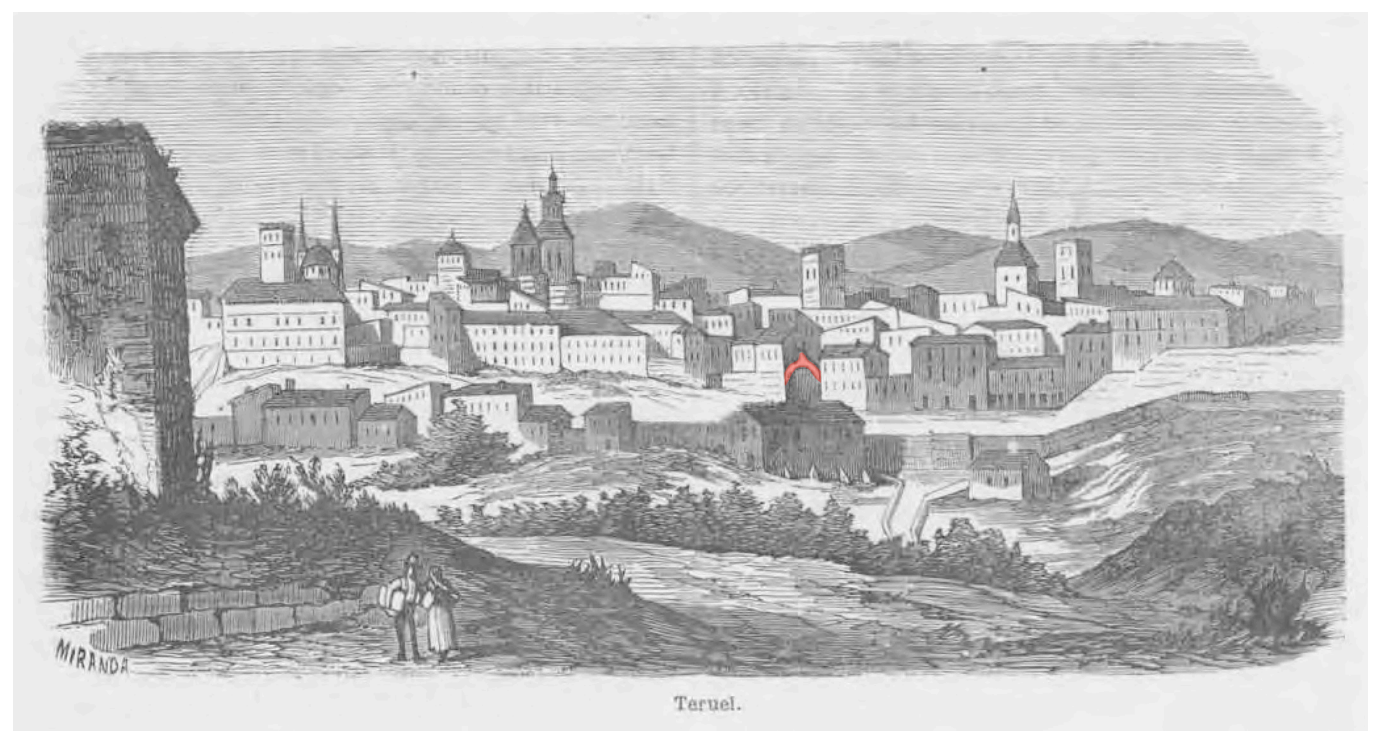




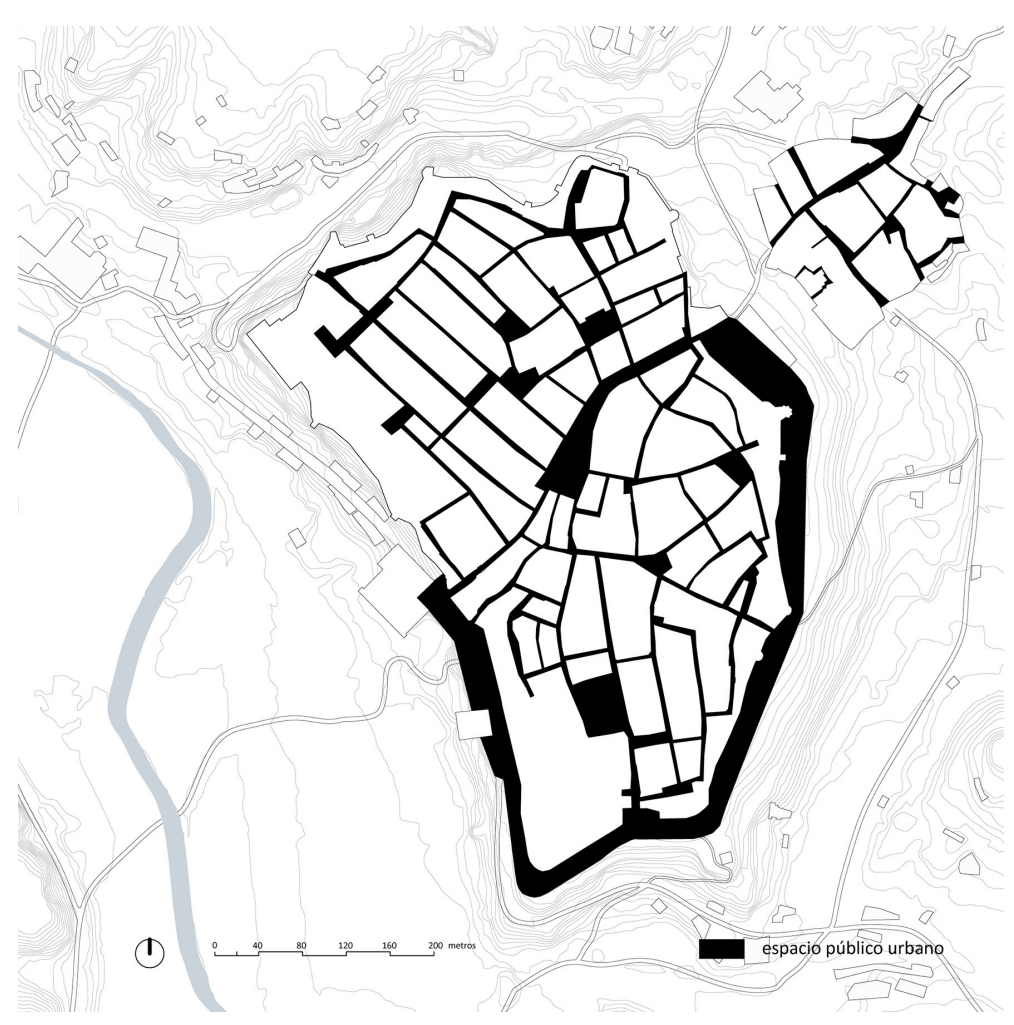

At the beginning of the $18^{\text {th }}$ century, the urban space spread beyond the limits of the wall [Alcorán, $12^{\text {th }}$ to $18^{\text {th }}$ century, fol. I 07], in a process of modernisation that evidenced greater concern for the creation and improvement of recreational spaces [Sancho, Agustín, Llopis $2017]$. Promenades and avenues were created around the town centre to improve health and sanitation with the planting of trees to enhance the quality of the environment.

By the mid- $18^{\text {th }}$ century, the town had a long and spacious promenade that from the northeast of the city circled round by the south until it reached the Guadalaviar gate. This promenade, conditioned by the primitive layout of the wall, was located outside the walls and on the hill, where there was previously a narrow path, so the hillside had to be terraced to allow the necessary space for its creation (fig. 5).

At the dawn of the $19^{\text {th }}$ century, the wall was in the process of abandonment, seen as an impediment to the expansion and modernisation of the urban space. Some parts of it were demolished and others were covered over, although it was still visible in long stretches of the perimeter [Miñano | 826-| 828, t.VIII, p. 423].

However, everything changed in the $19^{\text {th }}$ century as a result of the French occupation, and later, the defence of the town against the Carlists. The adaptation of the walled enclosure for its defence required a temporary complex fortification system [Sancho, Agustín, Martín 20 I7], involving a transformation that had a great impact on the town, modifying the morphology and function of the promenades that encircled the hill. A new wall was built enclosing these walkways, and the existing wall was modified and extended at some points, such as the section that joins the Agua and Bombardera turrets. The wall was made of plaster, of modest height and thickness that transformed the urban space into a bastioned system, already in decline at the time [Clairac I 884, III, p. I 59], but which allowed for a better defence of the site. Two accesses were fashioned to this new layout at the western cornice, one on the Paseo del Ovalo, which was reached from the Valencia road, and the other at the upper section of calle San Francisco, along with two of the medieval entrances that still remained, the Zaragoza gate to the east and the Daroca gate to the north. During this century, moreover, the building mass continued to grow, as occurred on the north-eastern and eastern façade of the town, where the back of many of the new buildings rested on the line of the wall forming the new façade of the promenade created in the $18^{\text {th }}$ cen- 
Fig. 5. Evolution of Teruel's

urban public space

until the 20th century

promenades.

Own drawing.
Fig. 6. Montage

highlighting the spaces of promenades and avenues between walls in the first Carlist war on a detailed

plan of Teruel in 1835 .

Note: Original rotated,

with north oriented to

the right. Own drawing (CEME I835 [plan]).
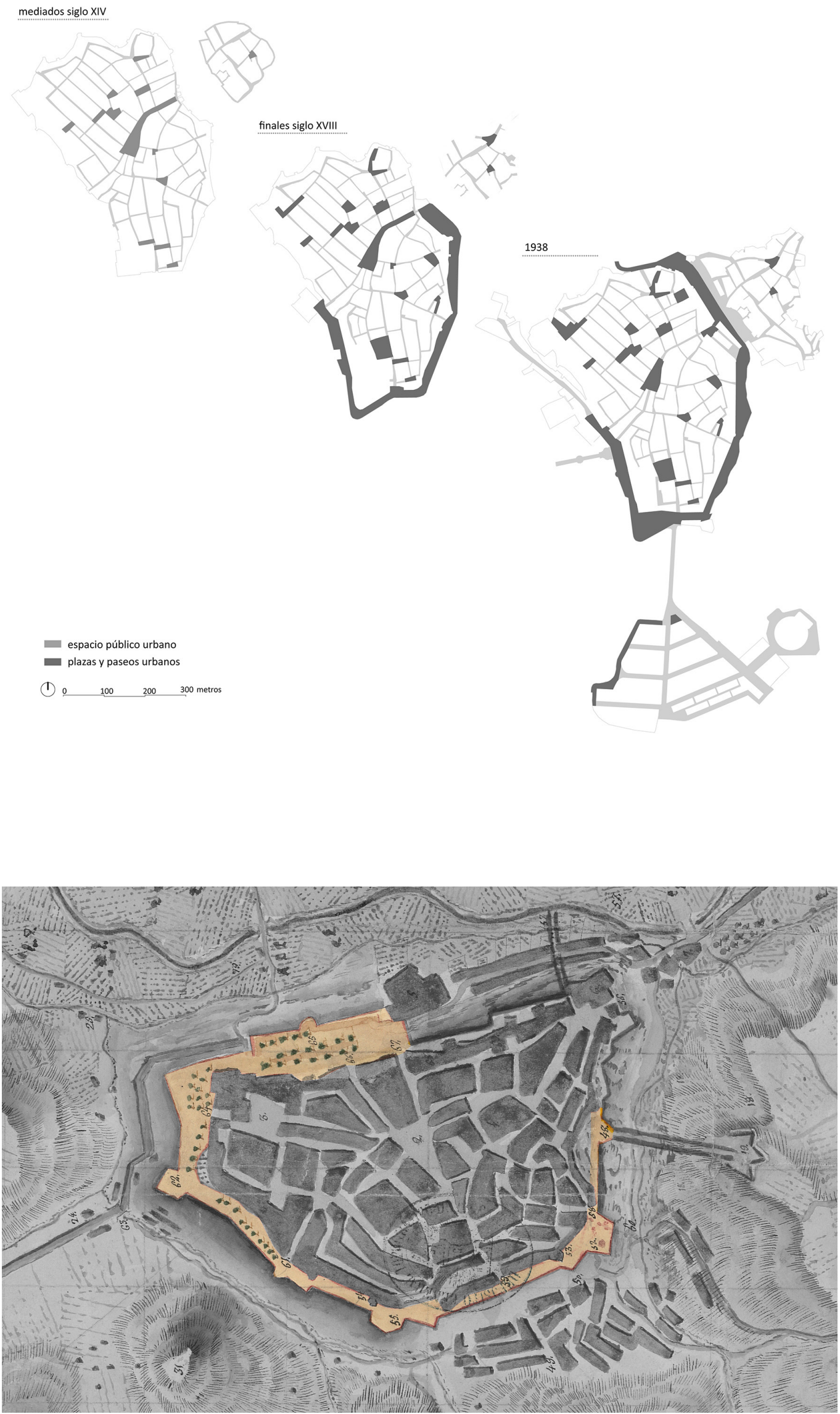
tury, a process that had already occurred during that century on the current Paseo del Ovalo, so that by 1866 very few sections were visible [Pruneda I 866, p. 33] (figs. 6, 7).

The construction of the Puente de la Reina to the north of the town, a project dated from 1835, transformed the function of the promenade that circled the wall, an arrangement that derived from the wall's layout, from a recreational space into a communication route for traffic, forming the road from Teruel to Alcañiz. The advent of the motor car consolidated this change and further undermined the original concept. Thus, the layout of this regional infrastructure, is a consequence of the arrangement of the primitive medieval wall. Furthermore, connecting with this ring road, in front of the old Valencia gateway, the Viaduct was built in 1929, which would provide a connection to the Sagunto road.

The Carlist wars were the last hostilities in which the wall played an important role, since, by the Civil War advances in weaponry had led to radical changes in the way conflicts were fought. After the devastation suffered, the project to rebuild the city was seen as an opportunity to renew the urban layout. Fortunately, the more reformist ideas designed to serve road traffic, which would have erased a large part of the medieval layout, did not proceed, while the proposal that was implemented, although it involved major changes, preserved a large part of the identity, the imprint of the historic city.

\section{Conclusions}

The wall is not a static element, but has undergone important processes of change since its construction in the $12^{\text {th }}$ century; formal and material transformations, degradation caused by the filling up of building space and its abandonment or as a consequence of periods of war, in such a way that the original configuration evolved and determined the shape of the city. The study of Teruel's historic cartography, which with new technologies was carried out with greater rigour and precision, has allowed us to verify the influence that the wall's layout had on the evolution of the urban morphology, from the initial construction of the urban fabric and structure, to the densifying of urban space caused by the limits imposed by the wall's presence, to the arrangements of many of the institutional buildings or the promenades as public spaces backed on to the wall's exterior, and later converted into circulation routes for the motor car. An imprint, as we have seen, that has endured in its trace memory until today, despite the lack of conserved remains.

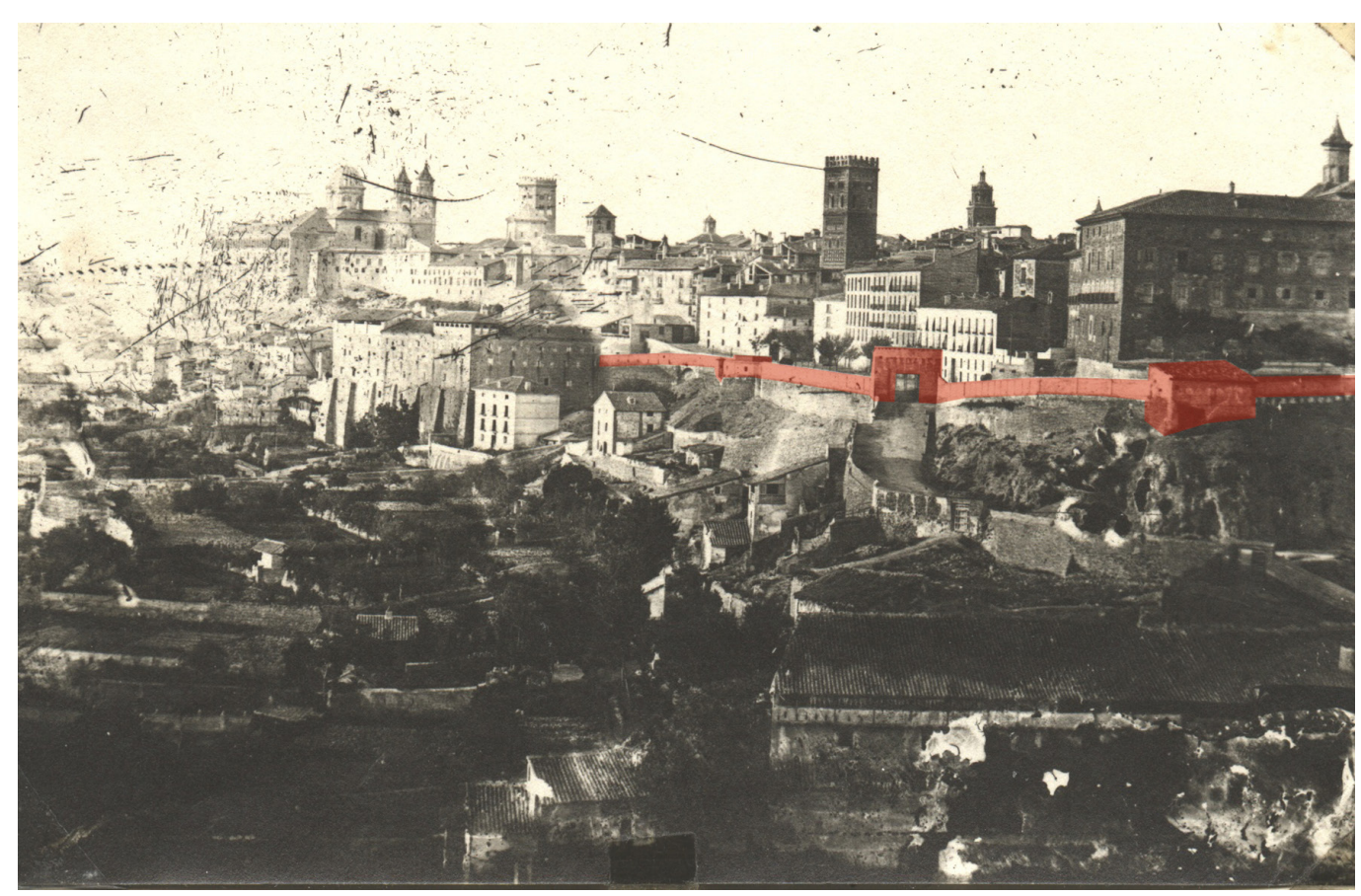




\section{Acknowledgment}

Work by researchers from the Grupo de Investigavción en Arquitectura (Architecture Research Group), GIA, of the University of Zaragoza, funded by the Government of Aragon (Reference Group T37_I7R) and co-financed with Feder 20I4-2020 "Building Europe from Aragon".

\section{Notes}

[I] In reality, there must have been more turrets than those depicted, but they have not been included because their exact location or form is not known.

\section{References}

Alcorán or Green Book. S. XII to S. XVIII [Manuscript]. Unpublished. Provincial Historical Archive of Teruel (AHPTE), Council / 36/03. 284 fol.

Arizaga Bolumburu B. (2002). La imagen de la ciudad medieval: la recuperación del paisaje urbano. Santander: Editorial of the University of Cantabria.

Balleti C. (2006). Georeference in the analysis of the geometric content of early maps. In e-Perimetron [electronic resoiurce] vol. I, n. I, pp. 32-42.

Clairac y Saénz P. (1 884) Diccionario general de arquitectura e ingeniería., volume III. Madrid: Press of A. Pérez Durrull.

Cuerpo del Estado Mayor del Ejército (España) (1835). Sketch of Teruel and its surroundings [map]. [ca. I: 6,800]. Unpublished. $560 \mathrm{~mm} \times 660 \mathrm{~mm}$. In España. Ministry of Defence. Institute of Military History and Culture. General Military Archive of Madrid. (IHCM_TE-3-4)

Gargallo Moya A.J. ( 1 996). El concejo de Teruel en la Edad Media, I I 77- I 327. Teruel: Department of Culture and Education of the Government of Aragon / Teruel City Council / Escucha City Council.

Miñano y Bedoya S. (I 826-I828). Diccionario geográfico-estadístico de España y Portugal., volume VIII. Madrid: Press of Pierart-Peralta.

Muñoz Garrido V. (2007). Teruel: de sus orígenes Medievales a la pérdida del fuero en 1598. Zaragoza: Ino Press.

Pruneda P. ( 1 866). Chronicle of the province of Teruel written by Pedro Pruneda. In Crónica general de España. Madrid: Ronchi and Co.

Sancho Mir M., Agustín Hernandez L., Llopis Verdú J. (2017a) Análisis y generación de cartografías historiográficas en el estudio de la evolución de la forma urbana: el caso de la ciudad de Teruel. In EGA Revista de expresión gráfica arquitectónica, vol. 30 pp. | 80- 189.

Sancho Mir M., Agustín Hernández L., Llopis Verdú J. (20 I7b). Hacia una nueva concepción del espacio público en el Teruel de la Edad Moderna: desde el S.XVI hasta el inicio del S.XIX. In ACE Architecture, City and Environment = Arquitectura , Ciudad y Entorno, n. 12 (35), pp. $191-212$

Sancho Mir M., Agustín Hernández L., Martín Domínguez B. (20 I7). La fortificación de Teruel durante el siglo XIX: un paisaje efímero. In Arqueología de la Arquitectura, n. 14

Temes Cordovez R. R. (2008). Las fuentes catastrales y la identificación de las transformaciones en los tejidos inversos. In CT: Catastro, n. 64, pp. 55-78 < http://www.catastro.meh.es/documentos/publicaciones/ct/ct64/n64_3.pdf> (accessed 202I, 23 February)

\section{Autohors}

Miguel Sancho Mir, Universidad de Zaragoza, misanmi@unizar.es

Beatriz Martín Domínguez, Universidad de Zaragoza, beamardo@unizar.es

Angélica Fernández-Morales, Universidad de Zaragoza, af@unizar.es

To cite this chapter. Sancho Mir Miguel, Martín Domínguez Beatriz, Fernández-Morales Angélica (2021). Relaciones entre la muralla y la forma urbana a través de la cartografía: el caso de Teruel/Relations between the Wall and Urban form through Cartography: the Case of Teruel. In Arena A Arena M Mediati D. Raffa P. (a cura di). Connettere Un disegno per annodare e tessere Linguagoi Distanze Tecnologie Atti del $42^{\circ}$ Convegno Internaziona de Proceedings of the 42th International Conference of Representation Disciplines Teachers. Milano: FrancoAngeli, pp. 2643-2658. 